\title{
Hanging in, but only just: part-time employment and in-work poverty throughout the crisis
}

\author{
Jeroen Horemans ${ }^{1 *}$, Ive Marx ${ }^{2}$ and Brian Nolan ${ }^{3}$
}

* Correspondence: jeroen.
horemans@uantwerpen.be
${ }^{1}$ Herman Deleeck Centre for Social
Policy, University of Antwerp,
SM-184 Sint-Jacobstraat 2, 2000
Antwerp, Belgium
Full list of author information is
available at the end of the article

available at the end of the article

\begin{abstract}
The crisis has deepened pre-existing concerns regarding low-wage and non-standard employment. Countries where unemployment increased most strongly during the crisis period also saw part-time employment increasing, particularly involuntary part-time work. With involuntary part-time workers, as a particular group of underemployed, facing especially high poverty rates, this was accompanied by an increase, on average, in the poverty risk associated with working part-time. However, this was not reflected in a marked increase in the overall in-work poverty rate because full-time work remains dominant and its poverty risk did not change markedly. The household context is of the essence when considering policy implications.
\end{abstract}

JEL codes: 132, 138, J21, J22, J68, R28

Keywords: In-work poverty, Part-time employment, Involuntary part-time employment, Crisis, Europe

\section{Introduction}

The global financial crisis has had important effects on work inequalities in Europe. Unemployment increased, in some cases dramatically, and even those countries that avoided widespread lay-offs through short-time working or partial unemployment schemes now face greater labour market segmentation. Non-standard employment has become more important, with temporary jobs sometimes the first to go when the crisis hit but more common among those then created, and with part-time employment growing throughout the crisis (Leschke 2012). Net job destruction coincided with an increase in precarious employment, especially involuntary part-time work (European Commission (2013a, 2014)). However, to date, concern about these developments has focused primarily on the implications for the individual in the labour market, both in terms of current pay penalty and chances of progressing in the future. The impact on poverty affecting their households has received little attention, even though part-time workers are known to be more likely than full-timers to be poor, especially when involuntarily part-time (Horemans and Marx 2013). This neglect is perhaps linked to the fact that in-work poverty as a whole has not generally risen during the crisis (Marx and Nolan 2014). That is the gap this paper seeks to fill, by reviewing what happened

(c) 2016 Horemans et al. Open Access This article is distributed under the terms of the Creative Commons Attribution 4.0 International License (http://creativecommons.org/licenses/by/4.0/), which permits unrestricted use, distribution, and reproduction in any medium provided you give appropriate credit to the original author(s) and the source, provide a link to the Creative Commons license, and indicate if changes were made. 
to the extent of part-time work, and particularly involuntary part-time, across EU member states and investigating its impact on poverty for those affected and on the extent of in-work poverty more broadly.

The paper is organized as follows: we first consider the complex nature of in-work poverty and examine why part-time workers are more likely to be poor. The next section empirically assesses the link between part-time employment and in-work poverty and how this was affected by the crisis. The final section concludes and discusses the implications for both policy and future research.

\section{Part-time work, in-work poverty, and the crisis: what would one expect to see?}

It is worth noting at the outset that there is considerable uncertainty, from a theoretical perspective, about how one might expect part-time work to be affected by recession and how that might then feed through to in-work poverty. Depending on the nature of the recession and the sectors most affected, but also on how part-time work is structured and the role it plays in the country in question, part-time workers may be more or less vulnerable to job loss in a crisis than full-timers. One might expect the involuntary element of part-time employment to increase and act as a buffer during economic downturns (Buddelmeyer et al. 2004) and that may be more pronounced for insecure secondary jobs, but the extent to which employers can and will avail of this buffer rather than simply lay off workers fully depends on the institutional setting and varies widely across countries.

The distinction between full-time and part-time work is of course itself not completely clear-cut, with an hours cut-off such as 30 or $35 \mathrm{~h}$ per week sometimes being used, but more often based on what the individual respondent in a survey considers to be the case. In a similar fashion, the distinction between voluntary and involuntary part-time work is not straightforward (OECD 2010). In practice, involuntary part-time workers are measured as those who say they would like but are unable to find a fulltime job, without a further specification of the number of hours worked (European Commission 2013b). There is particular debate about how to treat those combining part-time work with caring (Mayard et al. 2006; Jaumotte 2003; Gash 2008; McRae 1993, 2003; Perrons et al. 2007; Hakim 2000), since they may not be available to work more hours in the absence of supports but might respond differently in a more supportive institutional setting (Wilkins 2006).

As far as the impact of increasing part-time work on poverty is concerned, part-time workers face a higher poverty risk than full-timers on average, but that hides substantial variation among part-time workers and across countries (Horemans and Marx 2013). Part-time workers obviously earn less annually because they work less, but in addition, they often face a pay penalty that is largely driven by occupational segregation (Bardasi and Gornick 2008; O’Dorchai et al. 2007). Involuntary part-time workers in particular can be placed in between the unemployed and 'voluntary' part-timers for a number of characteristics that determine their lower level of earnings, including human capital indicators like skills and labour market history (Wilkins and Wooden 2011; Wilkins 2006), and job characteristics like occupation and local labour market conditions (Barrett and Doiron 2001). Hence, limited earnings are a first reason why the poverty risk of part-time workers in general and involuntary part-timers in particular is higher. 
While low individual earnings are an important part of the story, most low-paid individuals are not poor, essentially because poverty is (conventionally) assessed at the level of the household (Marx and Nolan 2014). The majority of the working poor are single earner households, whereas many part-time workers are in dual earner households. The poverty risk of part-time workers thus depends on the household context and varies widely across individuals for that reason but also across countries reflecting the differing roles that part-time work plays in the household income 'package' (Rodgers 2003; Debels 2008); (Horemans and Marx 2013). The fact that part-time jobs are often concentrated among women with caring responsibilities (Fouarge and Muffels 2008) also means that the households affected are more likely to include child and elderly dependants, which also affects their poverty risk since household income will be adjusted to take the number of persons relying on it into account in assessing poverty status. The final element in understanding the poverty risk for part-timers is social protection, and here, limited entitlements for part-timers to benefits may play an important role. Hours and/or earnings thresholds restrict access to unemployment benefits for parttime workers, especially for those in marginal or few-hours part-time jobs (Leschke 2007; OECD 2010). For other type of benefits like pensions and sickness, there may be restrictions as well (Buschoff and Protsch 2008). On the other hand, especially in countries where 'making work pay' has been prominent (Immervoll and Pearson 2009; Marx and Verbist 2008; Marchal and Marx 2015), there may be supports directed at parttime and other low-paid workers to maintain their link with the labour market (European Commission 2011). In the economic crisis, short-time work schemes to keep unemployment down have involved benefits (Hijzen and Venn 2011).

So the impact of an increase in the prevalence of part-time work on poverty will depend on how these key determinants of poverty risks for part-timer are affected. The wages of part-timers may have decreased or gone up during the crisis, depending on which jobs became redundant and which were created. The most insecure low-paid jobs are usually the first to go during the recession, but at the same time, labour law reforms allowed precisely more insecure low-level part-time jobs to be created (Lang et al. 2013). On the other hand, the poverty risk for some part-time workers may have been limited with the expansion of short-time work schemes (Hijzen and Venn 2011; Leschke 2012). The way household employment patterns changed may be even more important. In the initial phase of the crisis, a shift took place from dual to female breadwinner couples, which was more pronounced in countries that were hit the hardest (European Commission 2013c). A number of studies looking at the added worker effect during the recent crisis have found strongly variable patterns across Europe (Cho and Newhouse 2013; Ghignoni and Verashchagina 2012; Khitarsishvili 2013). An increase in male involuntary part-time employment may indicate short-time working to avoid lay-offs; a substantial increase in the numbers of involuntary female part-timers may suggest incomplete added worker effects (European Commission 2013c). This can explain why during the crisis the share of labour income obtained from part-time workers increased for households in the bottom quintiles (Bazen and Salverda 2015).

\section{What happened to part-time work in the crisis?}

We now look at what actually happened to the prevalence of part-time work and involuntary part-time in particular, across countries over the crisis. Table 1 illustrates the 
Table 1 Incidence and evolution part-time (PT) employment (\% of total employment) and involuntary part-time (IVP) (\% of part-time employment), age 15-64.

\begin{tabular}{|c|c|c|c|c|c|c|}
\hline & \multicolumn{3}{|c|}{ Part-time employment } & \multicolumn{3}{|c|}{ Involuntary part-time employment } \\
\hline & 2007 & 2010 & 2013 & 2007 & 2010 & 2013 \\
\hline$\overline{\text { AT }}$ & 22.0 & 24.4 & 26.0 & 12.2 & 11.5 & 11.7 \\
\hline BE & 21.9 & 23.7 & 24.3 & 14.8 & 11.4 & 9.5 \\
\hline BG & 1.5 & 2.2 & 2.5 & 60.6 & 54.4 & 61.8 \\
\hline CY & 6.4 & 8.3 & 11.9 & 30.7 & 34.7 & 55.8 \\
\hline$C Z$ & 4.4 & 5.1 & 5.8 & 14.8 & 15.8 & 16.9 \\
\hline DE & 25.4 & 25.5 & 26.7 & 22.6 & 21.9 & 15.6 \\
\hline DK & 23.0 & 25.6 & 24.7 & 13.4 & 15.6 & 18.3 \\
\hline EE & 7.1 & 9.8 & 8.9 & 15.7 & 22.1 & 18.5 \\
\hline ES & 11.4 & 12.9 & 15.7 & 33.3 & 50.1 & 63.3 \\
\hline $\mathrm{FI}$ & 13.4 & 13.9 & 14.0 & 25.2 & 27.9 & 26.1 \\
\hline FR & 17.2 & 17.6 & 18.1 & 31.5 & 31.7 & 39.3 \\
\hline GR & 5.4 & 6.3 & 8.4 & 45.1 & 54.7 & 68.2 \\
\hline $\mathrm{HU}$ & 3.9 & 5.5 & 6.4 & 28.0 & 35.8 & 43.2 \\
\hline IE & 17.4 & 22.2 & 23.5 & 10.9 & 32.5 & 43.1 \\
\hline IS & 21.1 & 22.4 & 20.8 & 5.5 & 21.7 & 17.6 \\
\hline IT & 13.4 & 14.8 & 17.6 & 39.5 & 50.5 & 63.0 \\
\hline LT & 8.6 & 7.8 & 8.4 & 28.1 & 39.2 & 32.7 \\
\hline LU & 17.8 & 17.5 & 18.7 & 5.2 & 7.9 & 10.6 \\
\hline LV & 5.6 & 9.4 & 7.5 & 25.6 & 42.3 & 40.7 \\
\hline MT & 10.6 & 11.6 & 14.2 & 16.7 & 19.6 & 16.0 \\
\hline $\mathrm{NL}$ & 46.3 & 48.3 & 49.8 & 5.1 & 5.7 & 9.9 \\
\hline$P L$ & 8.5 & 7.7 & 7.1 & 23.6 & 21.7 & 30.9 \\
\hline PT & 8.9 & 8.5 & 11.1 & 38.6 & 42.1 & 48.8 \\
\hline $\mathrm{RO}$ & 8.6 & 9.9 & 9.0 & 53.1 & 54.4 & 57.6 \\
\hline SE & 24.2 & 25.8 & 24.7 & 25.8 & 28.1 & 29.7 \\
\hline SK & 2.5 & 3.8 & 4.5 & 13.4 & 27.7 & 32.4 \\
\hline SL & 8.1 & 10.3 & 9.3 & 5.8 & 7.5 & 10.6 \\
\hline UK & 24.1 & 25.7 & 25.6 & 10.6 & & 20.3 \\
\hline EU-15 & 20.3 & 21.4 & 22.9 & 21.6 & 26.1 & 28.6 \\
\hline EU-27 & 17.6 & 18.6 & 19.7 & 22.4 & 26.7 & 29.4 \\
\hline
\end{tabular}

Source: Eurostat: EU-LFS

large variation in the levels as well as the evolutions of part-time employment and of the share that is done involuntarily. Data are taken from the Eurostat and based on the EU Labour Force Survey (EU-LFS) data ${ }^{1}$. The distinction between part-time and fulltime employment, and between involuntary and voluntary part-time, is based on the respondent's own description.

We see from Table 1 that involuntary part-time employment increased in most countries during the crisis, in several countries rising by more than ten percentage points. Countries with a very large increase in involuntary part-time jobs, in particular Southern European countries, had in 2007 a below average part-time rate but already had an above average involuntary part-time rate. The rise in involuntary part-time employment coincided with an above average growth in part-time work in Italy, Cyprus, 
Spain, and Ireland. However, an increase in part-time work over the crisis period was not necessarily involuntary as figures for Malta, Austria, and the Netherlands indicate. Only in Germany and Belgium involuntary part-time employment decreased (Table 1). Especially countries that suffered most in the initial phase of employment slack after the financial crisis (Southern European countries, the Baltic States, and Ireland) witnessed a substantial growth in involuntary part-time employment (Leschke 2012). The timing and duration of the crisis also matters. For example, Table 1 indicates that in the Baltic States the increase in involuntary part-time employment is concentrated between 2007 and 2010, but then, the overall economic situation ameliorated and we see that between 2010 and 2013 the share of involuntary part-time work stabilized. In Spain and Greece on the other hand, involuntary part-time employment continued to grow.

Figure 1 demonstrates the strong relationship between the recent increase in unemployment and involuntary part-time employment. A countercyclical outcome in (involuntary) part-time employment, comparable to unemployment, has been found in earlier research as well. When unemployment rises, people may be more willing to accept a part-time job while preferring a full-time job (Buddelmeyer et al. 2004). Comparative data also indicates that in less wealthy countries and in countries with more inequality, dissatisfaction with low working hours is higher (Stier and Lewin-Epstein 2003). This countercyclical growth of (involuntary) part-time employment raises concerns about an increase in in-work poverty because (involuntary) part-time workers are more likely to be poor.

\section{Poverty and part-time work: data, definitions, and method}

In studying the evolution of poverty for part-time workers over the crisis, we draw on data from the European Union Statistics on Income and Living Conditions (EU-SILC) 2008 and 2012. With the exception of Ireland and the UK, the income reference period is the previous calendar year. In Ireland, it is the year prior to the survey, and in the UK, current income is annualized (Eurostat 2011). These data are used as the main

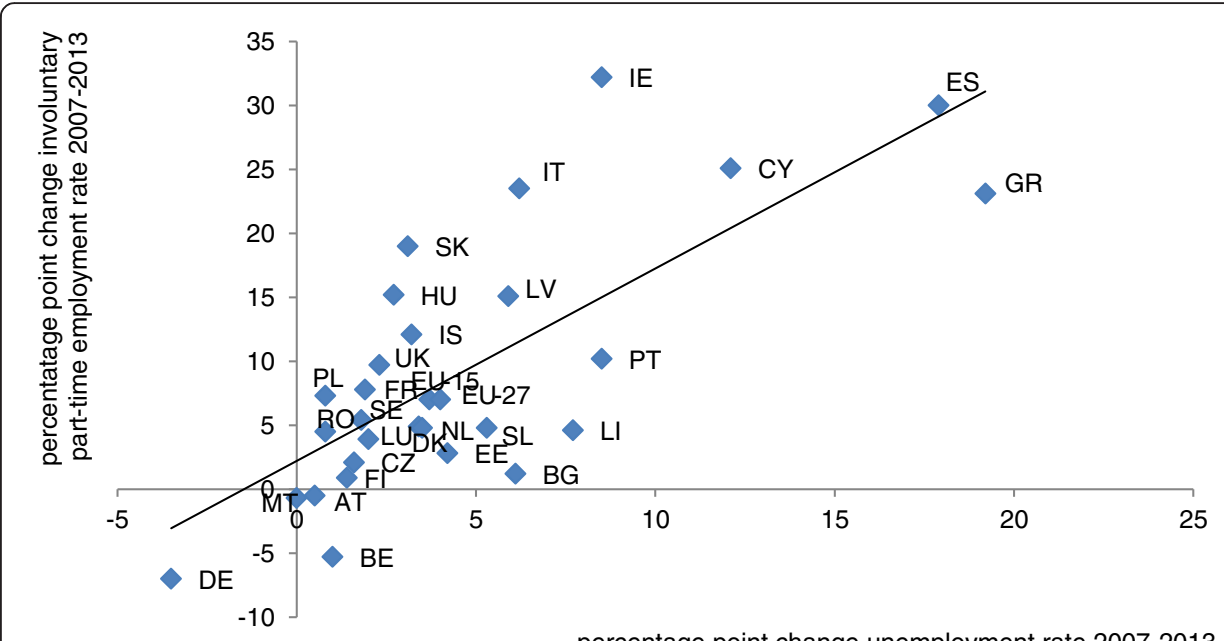

percentage point change unemployment rate 2007-2013

Fig. 1 Trends in unemployment and involuntary part-time employment in Europe, 2007-2013.

Source: Eurostat: EU-LFS 
source of information for understanding social exclusion and inequality across Europe. The reference population includes all private households and their current members residing in the territory of the countries at the time of data collection. All household members are surveyed, but only those aged 16 and more are interviewed (Eurostat 2010). EU-SILC data collection follows a uniform framework with shared guidelines and procedures as well as common concepts and classifications aimed at maximizing comparability of the data (Eurostat 2011; for an overview of potential comparability problems, see Lohmann 2011; van Oorschot 2012; Van Rie and Marx 2011).

The complexity of the working poor phenomenon can partially be traced back to its multi-layered definition and therefore deserves some attention. At the outset, research on in-work poverty in Europe employed a variety of definitions, based on different approaches of what was meant by 'being poor' and 'working' (for an overview, see Crettaz and Bonoli 2010; Peña-Casas and Latta 2004). Both concepts come from different research traditions with different units of analysis and reference periods. Employment refers to an individual's current labour market situations (ILO 1982), whereas the commonly adopted indicator for financial poverty in Europe is based on yearly disposable household income (Dennis and Guio 2003; Atkinson et al., 2002). EU-wide data development has stimulated the development of common indicators to measure social progress and also to the adoption of a standardized measurement of in-work poverty based on EU-SILC data, often referred to as the 'Eurostat definition'. Probably because the at-risk-of-poverty indicator was adopted as early as 2001 at the Laeken Council as a key indicator to monitor social inclusion (Atkinson et al. 2002), most of the critiques challenge the approach to measuring being 'in-work' ${ }^{2}$. Definitions of who is 'in-work' may cover a broad spectrum of how much individuals actually work during the income reference period.

The Eurostat indicator classifies individuals as employed according to their most frequent activity status, i.e. working at least 7 months during the income reference period of a year (Bardonen and Guio 2005). The Eurostat approach has some major advantages but also comes with some problems inherent to the combination of the two levels of analysis (Ponthieux 2010). Including periods of unemployment or inactivity may distract us from the real problem we are interested in (Halleröd and Larsson 2008). By focussing on full-year workers, we can ignore 'workers' who are poor because they did not work. Furthermore, focussing only on full-time full-year workers excludes the effect of low working hours on low income, and from a policy perspective, it is especially interesting to know why even working full-time full-year does not allow some individuals to avoid poverty (Nolan et al. 2012). The drawback of this approach is of course that a group of workers who is often most likely to have low earnings and experience difficulties in making ends meet is excluded from the analysis. Crettaz (2011) therefore proposes to adopt the ILO definition of 'working', entailing having worked at least $1 \mathrm{~h}$ in the week of the interview. This approach does not exclude a specific group of workers with weak labour market attachments.

In the empirical part, we adopt the common at-risk-of-poverty indicator. That is, someone is considered poor if her/his equivalent yearly disposable household income is below $60 \%$ of the national median level. The modified-OECD scale ${ }^{3}$ is used to account for economies of scale in consumption at the household level. This threshold reflects the minimum level of income considered necessary to have an acceptable standard of 
living relative to the society in which a person lives. It describes those below relative income thresholds as 'at-risk of poverty' rather than 'poor' since low household income is not the only factor leading to social exclusion.

Because we do not want to exclude workers with weak labour market attachments, we consider people to be 'working' if they indicate that this was their main activity status at the time of the interview. The analysis is limited to employees of working age (20 to 64 years). To define part-time employment, we adopt a cut-off of usually working less than $30 \mathrm{~h}$. We exclude the self-employed because data collection of their incomes is less reliable and part-time work seems a different condition than for employees.

EU-SILC data questions 'the reason for working less than 30 hours (in main and other jobs)' (European Commission 2012). This is used to make a distinction between voluntary and involuntary part-time workers. Involuntary part-time employment based on EU-SILC data can be seen as a synonym for underemployment where the employee 'wants to work more hours but cannot find a job(s) or work(s) of more hours' (Haataja et al. 2011). This contrasts the idea of involuntary part-time workers who are working part-time because they are merely 'unable to find a full-time job', without a further specification of the number of hours worked, as Eurostat figures based on EU-LFS data usually show (European Commission 2013b) ${ }^{4}$.

The next section examines the incidence and evolution of the poverty risk of parttime and full-time workers empirically. By adopting a straightforward decomposition in a similar way as de Beer (2007) and Corluy and Vandenbroucke (2014), we examine the change in in-work poverty.

$$
\begin{aligned}
\Delta \mathrm{IWP}= & \overline{\mathrm{PT}} * \Delta \mathrm{IWP}_{\mathrm{pt}}+\overline{\mathrm{FT}} * \Delta \mathrm{IWP}_{\mathrm{ft}}+\left(\mathrm{IWP}_{\mathrm{pt}}-\mathrm{IW}_{\mathrm{ft}}\right) * \Delta \mathrm{PT} \\
\Delta \mathrm{IWP}_{\mathrm{pt}}= & \overline{\mathrm{PT}}_{\text {invol }} * \Delta \mathrm{IWP}_{\text {invol }}+\overline{\mathrm{PT}}_{\mathrm{vol}} * \Delta \mathrm{IWP}_{\mathrm{vol}}+\left(\mathrm{IW} \overline{\mathrm{P}}_{\text {invol }}-\mathrm{IW} \overline{\mathrm{P}}_{\mathrm{vol}}\right) \\
& * \Delta \mathrm{PT}_{\text {invol }}
\end{aligned}
$$

The overall change in in-work poverty is attributed to the relative contribution of the change in the part-time poverty risk, the change in the full-time poverty risk, and the change in the share of part-time workers to Eq. 1. In addition, we also look at how the poverty rate of part-time workers changed by the share of involuntary part-timers and the changes in the poverty risk of voluntary and involuntary part-time workers (Eq. 2). Lastly, we apply a probit model, controlling for the typical in-work poverty mechanisms (Lohmann 2009; Goerne 2011) and including time dummies to gain a more finegrained perspective on the changes in in-work poverty in general and whether and why part-time employment became more problematic in Europe.

\section{Poverty risk for part-time versus full-time workers}

Turning to the empirical results, we first look at the level and evolution of the poverty risk of part-time and full-time workers. The figures may differ from the Eurostat figures, as we adopt an alternative definition because we do not want to exclude a priori the most precarious worker. A first observation from Figs. 2 and 3 is that poverty risks vary considerably more across countries for part-timers than full-timers. The part-time poverty rate is especially high in Southern and Eastern European countries, while it does not differ much from that of full-time workers in the Netherlands, Denmark, Sweden, Norway, and Czech Republic. Adopting a poverty threshold of half the median 


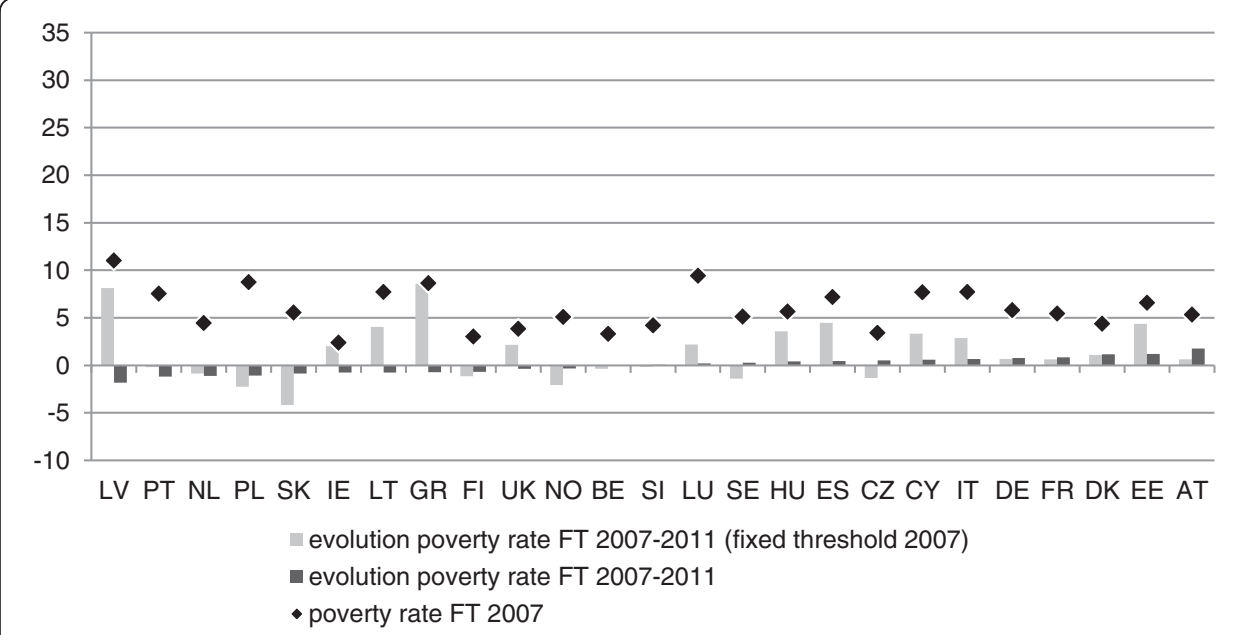

Fig. 2 Poverty rate 2007 and change in poverty rate 2007-2011 (in percentage points), full-time workers. Source: EU-SILC 2008 and 2012

household disposable income, OECD (2010) figures for 2005-2007 show that the depth of poverty is also more severe for part-timers in some Mediterranean and Eastern European countries. As with overall in-work poverty (Marx and Nolan 2014), no clear trend is seen over the crisis for poverty among full-time workers. For part-time workers, however, overall there is an increasing poverty rate between 2007 and 2011.

Figures 2 and 3 also show the trends with a fixed or 'anchored' poverty threshold, where the 2007 threshold adjusted for inflation is applied in 2011; where median income has actually fallen during the crisis, the relative poverty threshold will also have done so. The (higher) fixed poverty line is a valuable complement providing a more comprehensive picture. For full-timers, we now see that in the countries hit hardest by the crisis poverty now goes up with the fixed poverty line, while for part-timers an even stronger increase in the poverty risk than with the relative thresholds is seen.

Because in most countries both the share of part-time jobs and their poverty risk increased during the crisis, that may have had important consequences for the overall in-work poverty rate. In Fig. 4, we examine the respective contributions with a simple decomposition analysis similar to de Beer (2007). The overall change in in-work poverty is attributed to (1) the contribution of the change in the at-risk-of-poverty rate of full-time workers (change pov FT), (2) the contribution of the change in the at-risk-ofpoverty rate of part-time workers (change pov PT), and (3) the contribution of the change in the share of part-time workers (share PT). Of course this mechanical accounting approach should be interpreted with caution especially as underlying causal mechanisms are more complex and interrelated (de Beer 2007). The evolution of the poverty risk of full-time workers therefore mainly drives the overall change in in-work poverty, because in most countries, full-time employment remains the dominant form despite an increase in the share of part-time employment. In the UK, Sweden, Greece, Cyprus, Italy, and Spain, however, the increase in the poverty risk of part-time workers does appears to have contributed significantly to the change in in-work poverty. An increasing share in part-time employment was a significant factor in a rising overall inwork poverty rate in Latvia, Ireland, and Greece. Sweden appears an odd case, but there seems to be a problem with the data because for Sweden the data suggest a strong 


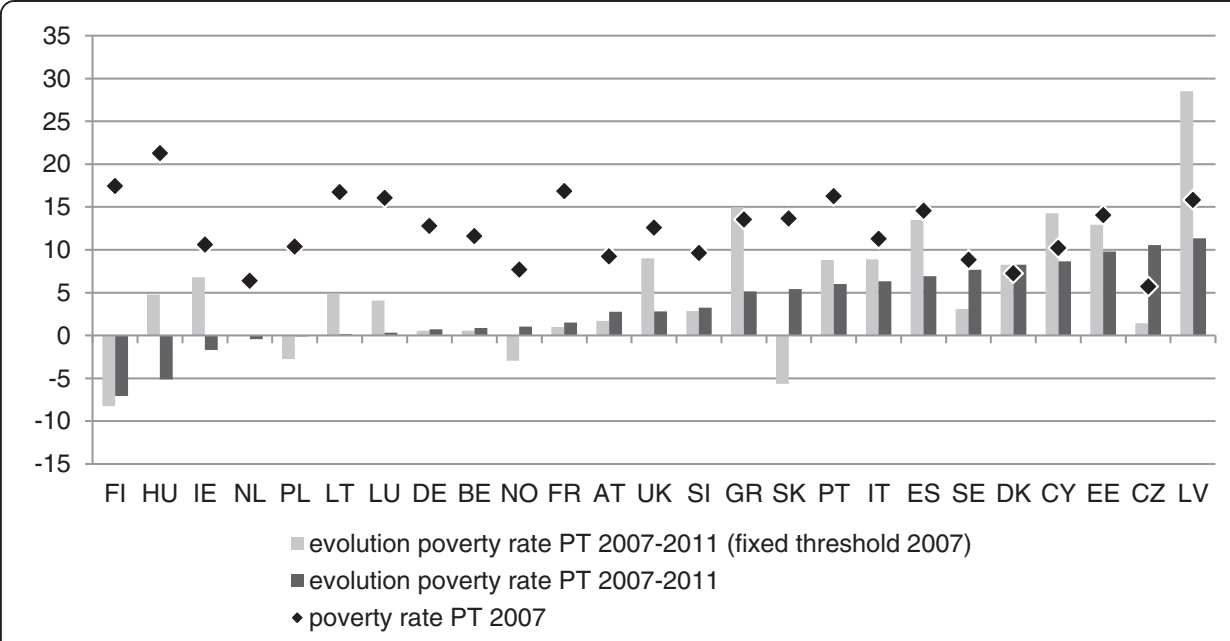

Fig. 3 Poverty rate 2007 and change in poverty rate 2007-2011 (in percentage points), part-time workers. Source: EU-SILC 2008 and 2012

decline in the share in part-time employment, which contrasts what we know from other data sources, like EU-LFS (see for example Table 1).

While overall the poverty risk of part-time workers increased across Europe, it did not necessarily lead to an increased overall in-work poverty risk. To further examine how the typical individual- and household-related characteristics responsible for an increased in-work poverty risk changed during the crisis period, we estimate a probit model where the dependent variable is poverty status and the explanatory variables include a set of country dummies (with the Netherlands as omitted reference category and estimated coefficients available upon request) and a range of individual, household, and job characteristics (for an overview of the descriptive statistics, see the Appendix). We focus in particular how the effect of working part-time changes vis-à-vis other changes in other covariates.

The results are given in Table 2. The models in Table 2 conceal substantial crossnational differences in the degree and drivers of in-work poverty; yet overall, they

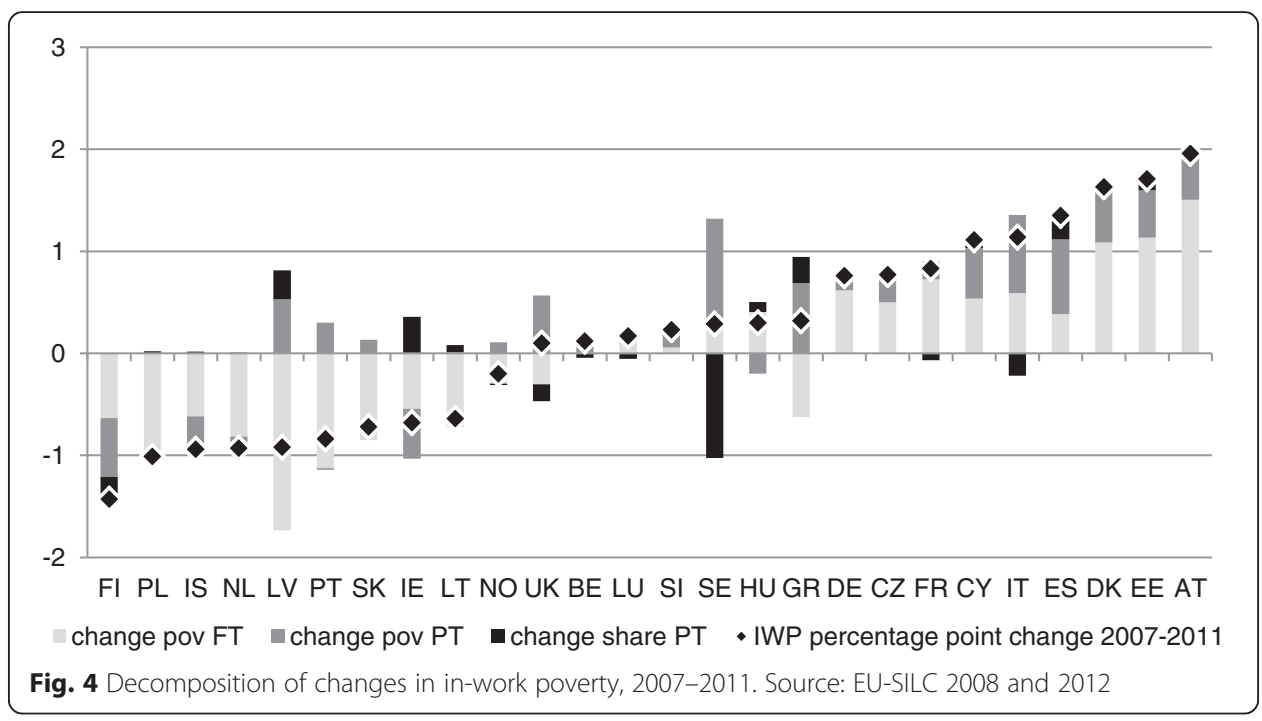


Table 2 Probit models for in-work poverty in Europe $(n=355,724)$.

\begin{tabular}{|c|c|c|c|c|c|c|}
\hline & Model 1 & & Model 2 & & Model 3 & \\
\hline Intercept & -2.24 & $* * *$ & -1.35 & $* * *$ & -1.40 & $* * *$ \\
\hline Part-time & 0.40 & $* * *$ & 0.39 & $* * *$ & 0.40 & $* * *$ \\
\hline D_2011 & -0.03 & $* * *$ & -0.05 & $* * *$ & 0.05 & $(*)$ \\
\hline Part-time * D_2011 & 0.10 & $* * *$ & 0.07 & $* *$ & 0.04 & * \\
\hline Women & & & 0.10 & $* * *$ & 0.10 & $* * *$ \\
\hline Middle skilled & & & -0.22 & $* * *$ & -0.22 & $* * *$ \\
\hline High skilled & & & -0.40 & $* * *$ & -0.40 & $* * *$ \\
\hline Age 30_49 & & & -0.15 & $* * *$ & -0.13 & $* * *$ \\
\hline Age 50_64 & & & -0.23 & $* * *$ & -0.21 & $* * *$ \\
\hline Not born in country & & & 0.42 & $* * *$ & 0.42 & $* * *$ \\
\hline Fam type: couple & & & -0.01 & & 0.01 & \\
\hline Fam type: other & & & -0.09 & $* * *$ & -0.03 & * \\
\hline WI other $\mathrm{HH}$ members & & & -1.23 & $* * *$ & -1.30 & $* * *$ \\
\hline 1 child & & & 0.25 & $* * *$ & 0.29 & $* * *$ \\
\hline 2 children & & & 0.45 & $* * *$ & 0.47 & $* * *$ \\
\hline$>2$ children & & & 0.72 & $* * *$ & 0.76 & $* * *$ \\
\hline $\mathrm{ISCO}=3$ & & & 0.14 & $* * *$ & 0.14 & $* * *$ \\
\hline $\mathrm{ISCO}=4$ & & & 0.28 & $* * *$ & 0.28 & $* * *$ \\
\hline $\mathrm{ISCO}=5$ & & & 0.54 & $* * *$ & 0.54 & $* * *$ \\
\hline $\mathrm{ISCO}=6,7$, or 8 & & & 0.51 & $* * *$ & 0.51 & $* * *$ \\
\hline $\mathrm{ISCO}=9$ & & & 0.75 & $* * *$ & 0.75 & *** \\
\hline Full-year working & & & -0.76 & $* * *$ & -0.76 & $* * *$ \\
\hline UNEMPL benefit & & & 0.23 & $* * *$ & 0.20 & *** \\
\hline Benefit & & & -0.30 & $* * *$ & -0.31 & $* * *$ \\
\hline Age 30_49* D_2011 & & & & & -0.05 & * \\
\hline Age 50_64 * D_2011 & & & & & -0.05 & $* * *$ \\
\hline Couple * D_2011 & & & & & -0.03 & \\
\hline Other * D_2011 & & & & & -0.13 & * \\
\hline WI other HH members * D_2011 & & & & & 0.14 & *** \\
\hline 1 child * D_2011 & & & & & -0.08 & $* * *$ \\
\hline 2 children * D_2011 & & & & & -0.03 & \\
\hline >2 children * D_2011 & & & & & -0.07 & * \\
\hline UNEMPL benefit * D_2011 & & & & & 0.05 & * \\
\hline Pseudo $R^{2}$ & 0.0419 & & 0.2532 & & 0.2538 & \\
\hline
\end{tabular}

Source: EU-SILC 2008 and 2012, all models control for country dummies. Reference: full-time, D_2007, men, low skilled, age 20_29, born in country, fam type: single, 0 children, ISCO 1 or 2, not full-year working, no UNEMPL benefit, no benefit

Significance levels: $\left({ }^{*}\right) p<0.1 ;{ }^{*} p<0.05 ;{ }^{* *} p<0.01 ;{ }^{* *} p<0.001$

consistently indicate that part-time workers are indeed more likely to be poor than full-time employees in both years (as indicated by the significant positive coefficient on the dummy for part-time) and that this gap increased during the crisis (as indicated by the significant positive coefficient on the interaction between that dummy and the later year).

As regards individual-level characteristics we control for in model 2, we see that women, low skilled, youngsters, and people not born in the country are more likely to 
be poor when working, confirming previous research (Lohmann 2009; Goerne 2011). As also expected from previous studies, overall resources and needs at the household level matter greatly for understanding in-work poverty. The poverty risk increases with the number of children, while it decreases with work intensity of other household members ${ }^{5}$. Personal resources matter as well. Managers and professionals, who are more likely to earn more, and people with stable jobs have a lower poverty risk. From Table 2, we also see that workers who received some kind of unemployment benefit during the income reference period, indicating an insecure labour market attachment, are more likely to be poor than other workers. Yet, if we control for all possible types of benefits, in-work poverty tends to be lower for those combining work and benefits. Hence, it clearly matters how work and welfare is combined.

Adding control variables and interactions, first without and then with a time dummy in columns 2 and 3, respectively, the estimated impact of part-time working per se diminishes and the interaction between part-time and year is no longer strongly significant. This suggests that the composition of part-time workers contributes to their enhanced poverty risk and that changes in composition contributed to its increase, although care must be exercised in interpreting the interaction terms in these kinds of non-linear models (Ai and Norton 2003; Norton et al. 2004).

\section{Involuntary part-time and in-work poverty}

To investigate the implications of the heterogeneous nature of part-time employment for poverty risk, we now distinguish between voluntary and involuntary part-time employment. As indicated earlier, involuntary part-time employment as captured in EUSILC is more an indication of underemployment as it only considers people working less than $30 \mathrm{~h}$. Involuntary part-time workers stated to be looking for a full-time job or to work more hours, whereas voluntary part-timers indicated that they do not want to work more hours, work part-timers because of caring activities, sickness, disability, education, or other not-further-specified reasons. To what extent part-time work is done for 'care' reasons is to be considered as an entirely voluntary choice is of course debatable (OECD 2010). Respondents stating that they work less than $30 \mathrm{~h}$ but explicitly report that it is a full-time job are excluded in figures that make a distinction between voluntary and involuntary part-timers.

Table 3 looks at the poverty risk associated with working part-time involuntarily, compared with voluntary part-timers, full-timers, and the unemployed. It confirms earlier figures showing that involuntary part-time work is particularly associated with problematic living standards (Wilkins 2007; OECD 2010). The difference in the poverty risk between unemployed and involuntary part-time workers is in a number of countries not statistically significant. Compared to voluntary part-time workers, involuntary parttime workers are more likely to be poor in most countries. However, we also see that the problem of in-work poverty among part-time workers is not solely confined to those working part-time involuntarily. Indeed, Denmark, Greece, Iceland, Italy, Lithuania, Luxembourg, Poland, Portugal, and Slovenia are the only countries where the poverty risk of voluntary part-time workers is not significantly higher than full-time workers.

Focusing on what happened with the part-time poverty rate during the crisis, we decompose the overall change into the changes in risk for voluntary and involuntary part- 
Table 3 Poverty risk of involuntary part-time workers, voluntary part-time workers, full-time workers, and unemployed.

\begin{tabular}{|c|c|c|c|c|c|c|c|}
\hline & $\begin{array}{l}\text { Involuntary } \\
\text { part-time }\end{array}$ & $\begin{array}{l}\text { Voluntary } \\
\text { part-time }\end{array}$ & & Full-time & & Unemployed & \\
\hline AT & 31.2 & 10.0 & ** & 7.1 & ${ }^{* *}\left[{ }^{*}\right]$ & 40.3 & \\
\hline BE & 31.5 & 8.4 & $* * *$ & 3.3 & $\left.* * *{ }^{* *}\right]$ & 38.3 & \\
\hline CY & 23.9 & 14.3 & $(*)$ & 8.3 & $* *\left[\left({ }^{*}\right)\right]$ & 21.2 & \\
\hline$C Z$ & 37.2 & 9.6 & $* *$ & 3.9 & $* * *\left[\left({ }^{*}\right)\right]$ & 41.0 & \\
\hline DE & 37.7 & 10.7 & $* * *$ & 6.5 & $* * *[* * *]$ & 66.3 & $* * *$ \\
\hline DK & 38.0 & 18.1 & & 5.5 & ${ }^{*}[]$ & 28.7 & \\
\hline EE & 39.3 & 16.4 & $* *$ & 7.8 & $*^{* *}\left[\left({ }^{*}\right)\right]$ & 44.5 & \\
\hline ES & 27.5 & 16.0 & $* * *$ & 7.6 & $\left.* * *{ }^{* * *}\right]$ & 40.2 & $* * *$ \\
\hline $\mathrm{FI}$ & 24.2 & 11.8 & $(*)$ & 2.3 & $\left.* * *{ }^{* *}\right]$ & 38.8 & * \\
\hline$F R$ & 29.1 & 12.8 & $* * *$ & 6.2 & $* * *\left[{ }^{* *}\right]$ & 30.7 & \\
\hline GR & 28.4 & 21.8 & & 7.9 & $* * *[]$ & 43.1 & $* *$ \\
\hline $\mathrm{HU}$ & 22.3 & 12.0 & * & 6.1 & $* * *\left[{ }^{*}\right]$ & 42.6 & *** \\
\hline IE & 10.7 & 8.1 & & 1.6 & ${ }^{* *}\left[{ }^{* * *}\right]$ & 32.2 & *** \\
\hline IS & 16.1 & 4.2 & & 3.4 & [ ] & 19.4 & \\
\hline IT & 24.5 & 11.0 & $* * *$ & 8.4 & $* * *[]$ & 40.1 & $* * *$ \\
\hline LT & 34.0 & 12.3 & $* *$ & 7.0 & $* * *[]$ & 52.6 & * \\
\hline LU & 37.8 & 11.5 & $* *$ & 9.6 & ${ }^{* *}[]$ & 45.3 & \\
\hline LV & 38.8 & 17.3 & $* * *$ & 9.2 & $\left.* * *{ }^{*}\right]$ & 45.6 & \\
\hline $\mathrm{NL}$ & 22.7 & 4.4 & $* * *$ & 3.3 & $*^{* *}[]$ & 23.1 & \\
\hline NO & 19.1 & 9.0 & & 4.8 & ${ }^{*}[(*)]$ & 32.1 & $(*)$ \\
\hline$P L$ & 23.2 & 7.8 & $* * *$ & 7.7 & $* * *[]$ & 36.4 & $* *$ \\
\hline PT & 29.0 & 12.2 & $* *$ & 6.4 & $* * *[]$ & 32.8 & \\
\hline SE & 30.1 & 15.6 & * & 5.4 & $*^{* *}\left[{ }^{* *}\right]$ & 33.7 & \\
\hline SI & 30.0 & 7.3 & $* *$ & 4.2 & $* * *[]$ & 37.0 & \\
\hline SK & 24.5 & 15.5 & & 4.7 & $\left.* *{ }^{*}\right]$ & 41.3 & * \\
\hline UK & 27.1 & 12.4 & $* * *$ & 3.5 & $* * *[* * *]$ & 53.2 & $* * *$ \\
\hline
\end{tabular}

Source: EU-SILC 2012

Significantly different from involuntary part-time: $\left({ }^{*}\right) p<0.1 ;{ }^{*} p<0.05 ;{ }^{* *} p<0.01 ;{ }^{* *} p<0.001$. Significantly different from voluntary: [similar significance levels]

timers and the share of involuntary part-time work (Fig. 5), as before. In Fig. 5, no clear overall picture arises. The changes in the poverty risk of part-time workers are also not solely driven by the poverty risk associated with involuntary part-time work. However, there are indications that the increase in the share of involuntary part-time employment went hand in hand with an increase in poverty among part-time workers, as Fig. 6 brings out.

Looking more closely at the covariates associated with poverty risk for part-time workers, the probit models estimated for these workers only presented in Table 4 show that working part-time voluntarily is associated with a lower risk of being poor in both years, though that gap does not widen over the period despite the overall increase in risk associated with working part-time. For an overview of the descriptive statistics, see the Appendix.

If the increase in the poverty risk of part-time workers tends to be associated with the growing share of part-time workers who do so involuntarily, why did that share increase during the crisis? Earlier research mentions specifically gaps in job quality and pay levels between voluntary and involuntary part-timers as potential drivers of involuntary part-time employment (Veliziotis et al. 2015). On the other hand, as many countries 


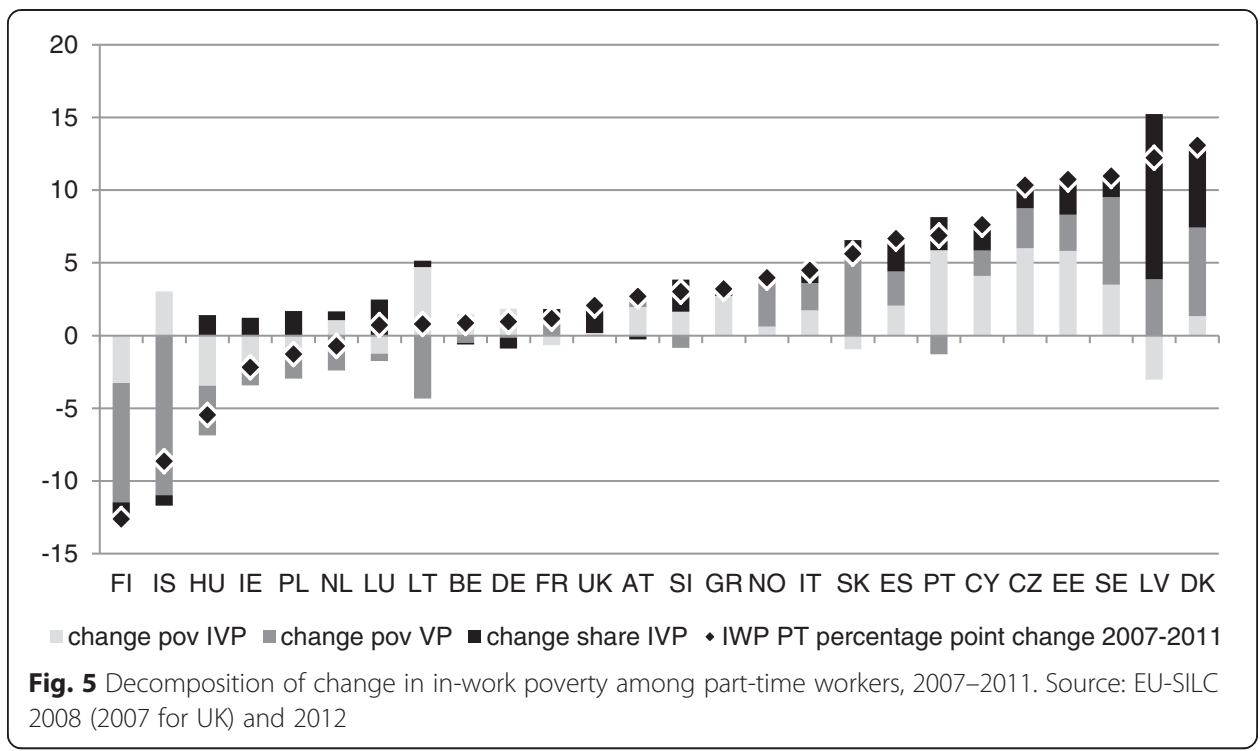

increased their short-time work schemes and partial unemployment schemes (Hijzen and Venn 2011; Vaughan-Whitehead 2011), involuntary part-time rate may have increased more in countries where part-timers became more likely to receive additional unemployment benefits. Yet, as part-time employment often serves as a secondary income provided by women, the poverty risk is likely to be higher if men work part-time as primary earners. Hence, the increase in the poverty risk of female part-time workers can be understood by a decrease in dual earnership since especially male employment decreased during the crisis. Added worker effects are expected to increase female labour supply in these circumstances. However, empirical evidence suggest that women tend to be highly limited from the demand side and are unable to materialize the job search activities (Bredtmann et al. 2014). Therefore, the causes of the increase in involuntary part-time work should not merely be sought in individual precarious labour market situations of low pay or unstable employment

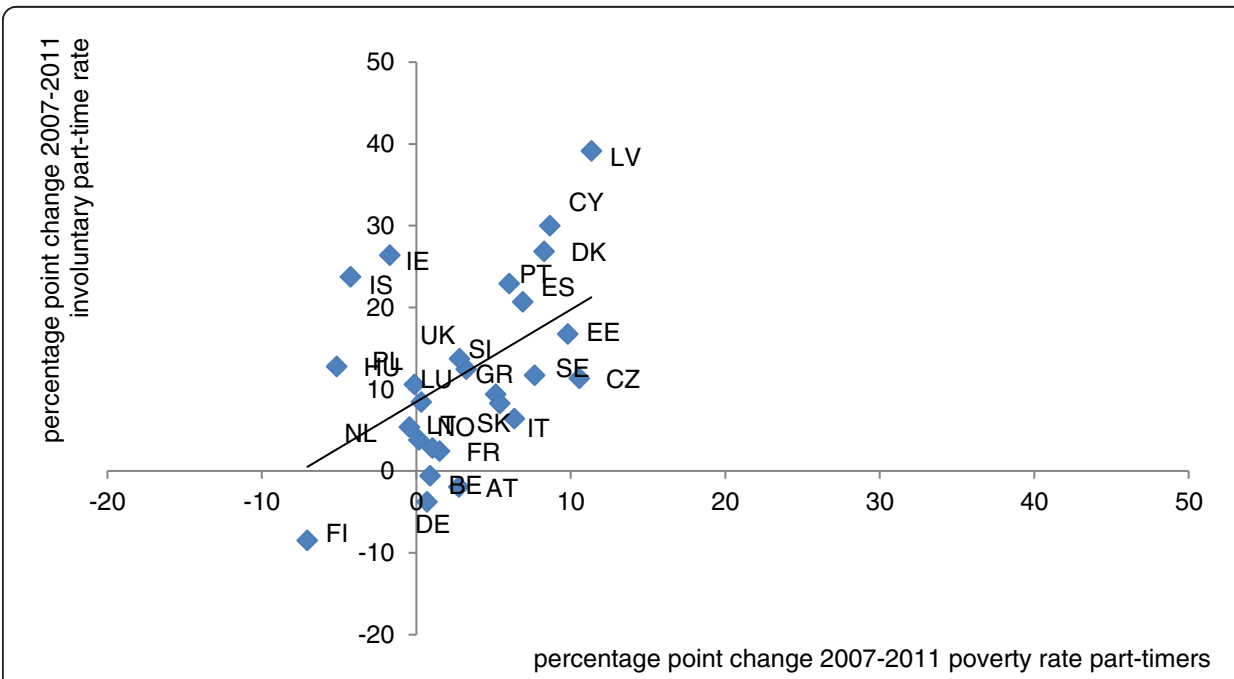

Fig. 6 Trends in involuntary part-time employment and the poverty risk of part-time workers in Europe ( $r=0.48), 2007-2011$. Source: EU-SILC 2008 (2007 for UK) and 2012 
Table 4 Probit models for in-work poverty among part-time workers in Europe $(n=27,364)$.

\begin{tabular}{|c|c|c|c|c|c|c|}
\hline & Model 1 & & Model 2 & & Model 3 & \\
\hline & -1.38 & $* * *$ & -0.34 & $* * *$ & -0.32 & $* * *$ \\
\hline Voluntary part-time & -0.57 & $* * *$ & -0.32 & $* * *$ & -0.32 & $* * *$ \\
\hline D_2011 & 0.03 & & -0.04 & & -0.07 & \\
\hline Voluntary part-time * D_2011 & -0.05 & & -0.01 & & -0.02 & \\
\hline Women & & & -0.16 & $* * *$ & -0.24 & $* * *$ \\
\hline Middle skilled & & & -0.18 & $* * *$ & -0.18 & $* * *$ \\
\hline High skilled & & & -0.32 & $* * *$ & -0.31 & $* * *$ \\
\hline Age 30_49 & & & -0.02 & & -0.03 & \\
\hline Age 50_64 & & & -0.24 & $* * *$ & -0.24 & $* * *$ \\
\hline Not born in country & & & 0.34 & $* * *$ & 0.41 & $* * *$ \\
\hline Fam type: couple & & & -0.33 & $* * *$ & -0.33 & $* * *$ \\
\hline Fam type: other & & & -0.49 & $* * *$ & -0.49 & $* * *$ \\
\hline Wl other $\mathrm{HH}$ members & & & -1.25 & $* * *$ & -1.25 & $* * *$ \\
\hline 1 child & & & 0.18 & $* * *$ & 0.27 & $* * *$ \\
\hline 2 children & & & 0.35 & $* * *$ & 0.40 & $* * *$ \\
\hline$>2$ children & & & 0.54 & $* * *$ & 0.52 & $* * *$ \\
\hline $\mathrm{ISCO}=3$ & & & -0.04 & & -0.04 & \\
\hline $\mathrm{ISCO}=4$ & & & 0.19 & $* * *$ & 0.19 & $* * *$ \\
\hline $\mathrm{ISCO}=5$ & & & 0.35 & $* * *$ & 0.35 & $* * *$ \\
\hline $\mathrm{ISCO}=6,7$, or 8 & & & 0.37 & $* * *$ & 0.37 & $* * *$ \\
\hline $\mathrm{ISCO}=9$ & & & 0.55 & $* * *$ & 0.55 & $* * *$ \\
\hline FY working & & & -0.51 & $* * *$ & -0.51 & $* * *$ \\
\hline UNEMPL benefit & & & 0.31 & $* * *$ & 0.31 & $* * *$ \\
\hline Benefit & & & -0.57 & $* * *$ & -0.58 & $* * *$ \\
\hline Women * D_2011 & & & & & 0.14 & * \\
\hline Not born in country * D_2011 & & & & & -0.12 & * \\
\hline 1 child * D_2011 & & & & & -0.16 & $* *$ \\
\hline 2 children * D_2011 & & & & & -0.09 & \\
\hline >2 children * D_2011 & & & & & 0.00 & \\
\hline Pseudo $R^{2}$ & 0.0305 & & 0.2670 & & 0.2678 & \\
\hline
\end{tabular}

Source: EU-SILC 2008 and 2012, all models control for country dummies (UK not included). Reference: involuntary parttime, D_2007, men, low skilled, age 20_29, born in country, fam type: single, 0 children, ISCO 1 or 2, not full-year working, no UNEMPL benefit, no benefit

Significance levels: $\left({ }^{*}\right) p<0.1 ;{ }^{*} p<0.05 ;{ }^{* *} p<0.01 ;{ }^{* *} p<0.001$

but with the overall realization of the household work potential that enables workers to provide a decent living standard. As Fig. 7 demonstrates, an increase in the proportion of part-timers who are the only earner in the household is strongly associated with increasing poverty risk.

\section{Conclusions}

The crisis deepened pre-existing concerns regarding work inequalities in Europe, especially those arising from the growth in low-wage and non-standard employment. Countries where unemployment increased most strongly during the crisis period also saw part-time employment increasing, in particular involuntary part-time work. This growth in part-time jobs was accompanied by an increase, on average, in the poverty 


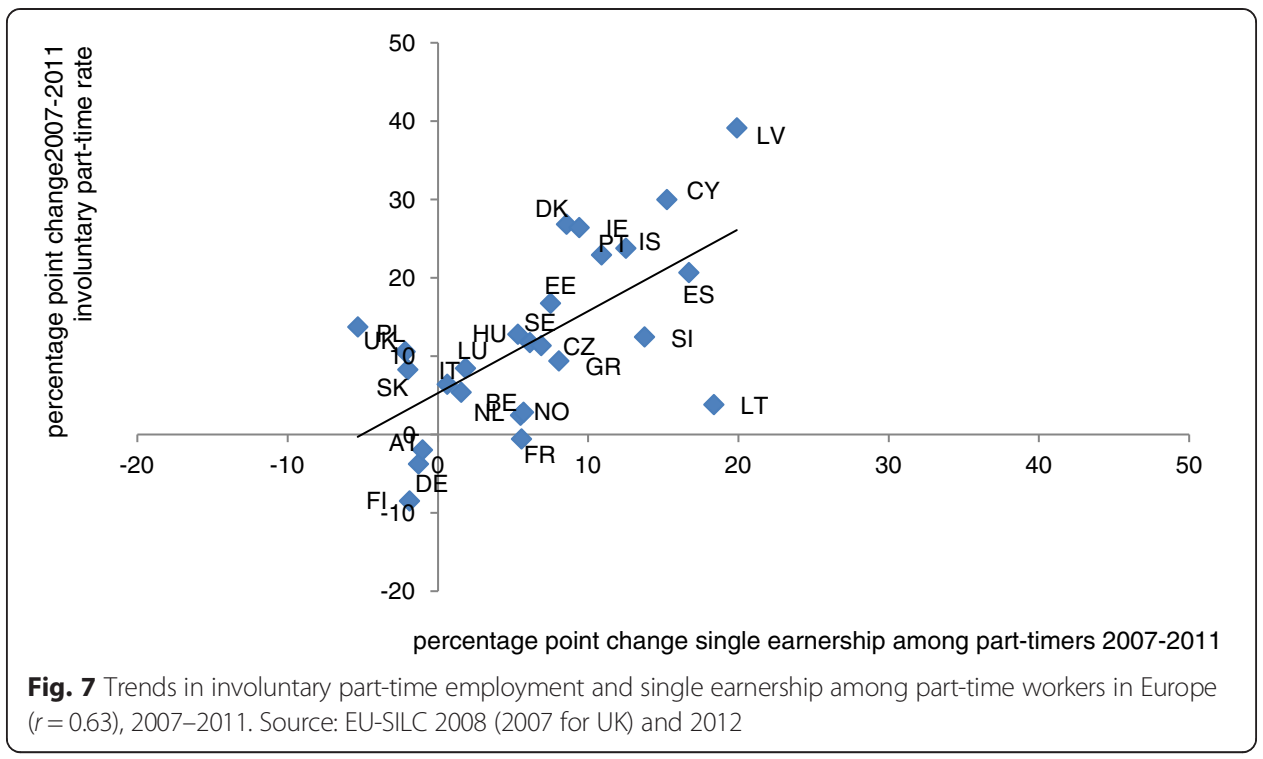

risk associated with working part-time. This was not reflected in a marked increase in the overall in-work poverty rate because full-time work remains dominant and its poverty risk did not change markedly. In a situation where median incomes-and relative thresholds derived from them-have fallen, it is important to also look at poverty vis-à-vis thresholds held fixed in purchasing power terms. These show an increase in the poverty risk for both full-time and part-time workers in a number of Southern and Eastern European countries during the crisis. Involuntary part-time employment, as a specific form of underemployment, is associated with particularly high poverty rates and ones which rose in many countries during the crisis.

As far as policy responses are concerned, because household work intensity takes a central place in the variety of drivers of in-work poverty in Europe, this should also be central in the debate when considering policy options to tackle in-work poverty in general and also when focussing on specific group workers with low earnings. Broadly speaking, we can make a distinction between direct and indirect income support on the one hand and incremental' (augmenting existing provisions) and 'new' (which replace or complement existing provisions) policy options on the other (for a detailed discussion of policy options, see Marx and Nolan 2014). As regards involuntary part-time workers in particular, indirect income support through a facilitation of full-time participation appears a straightforward option. However, given the scarcity of work in times of crisis, this is perhaps in the short run not feasible. Furthermore, even for full-time full-year workers, single earnership is problematic from a poverty perspective if it has to cover the needs for an entire household with other non-working household members (Nolan et al. 2012). From a short-term incomeprotection objective, especially in times of crisis, direct income support through child benefits, substantial replacement income for unemployed adults, and/or in-work benefits appear the way forward.

In-work benefits are one of new policy options attracting much interest in the public debate and in the academic literature (Kenworthy 2011; Crettaz 2011; Allègre and Jaehrling 2011; Marx et al. 2012). Anglo-Saxon-type of tax credits clearly have their merits in making work pay but also have some serious limitation as regards universal 
applicability as they are only effective in particular socio-demographic and economic settings and for particular groups (Marx and Nolan 2014).

Interestingly, we found that workers who are combining their earnings with unemployment benefits during the income reference period-indicating an unstable work attachment-tend to have a higher poverty risk while workers who combine it with other types of benefit are less likely to be poor. Generally speaking, however, in-work poverty tends to be lower for those combining work and benefits. Hence, it clearly matters how work and welfare is combined. These combinations of work and welfare should be explored further as they possibly mask existing in-work benefits that have remained under the radar of the debate. Unfortunately, EU-SILC data does not allow a detailed analysis, so countryspecific, preferably administrative, data are needed to analyse whether these benefits are associated with very short periods of full unemployment, involuntary short-time work, voluntary types of leave, or a compensation for other specific circumstances.

\section{Endnotes}

${ }^{1 /}$ The EU Labour Force Survey (EU-LFS) is the largest European household sample survey, providing quarterly and annual data on labour participation of people aged 15 and over and on persons outside the labour force (...). The LFS is an important source of information on the situation and trends in the EU labour market.' (Eurostat 2015). Because income is not questioned in this survey, we adopt EU-SILC data in the empirical section to examine in-work poverty more in detail (for more information on EU-SILC data, please see Section 4).

${ }^{2}$ For discussions regarding the measurement poverty in the in-work poverty literature, see for example Peña-Casas and Ghailani (2011) on the individualisation of the poverty risk ignoring the assumption of equal sharing within the household or Allègre and Jaehrling (2011) on alternative ways of calculation of poverty thresholds for workers only. For a systematic discussion on the potential of EU-SILC data to examine the relationship between work and poverty, see Lohmann (2011).

${ }^{3}$ The equivalence scale used is the OECD-modified scale ( 1 for the first adult, other adults correspond to 0.5 equivalent adult, and each child under 14 corresponds to 0.3 equivalent adults in terms of needs); the use of an equivalence scale is necessary in order to be able to compare households of various size and composition and to account for the economies of scale in multi-person households.

${ }^{4}$ The different answer categories differ across surveys and hence potentially affect the degree of involuntary part-time work. For example, other response categories in EU-SILC are (1) undergoing education or training, (2) personal illness or disability, (3) do not want to work more hours, (4) number of hours are considered as a full-time job, (5) housework, looking after children or other persons, and (6) other reasons (European Commission 2012). Other response categories in EU-LFS are (1) undergoing school education or training, (2) own illness or disability, (3) looking after children or incapacitated adults, (4) other family or personal reasons, and (5) other reasons (European Commission 2013b).

${ }^{5}$ Work intensity (WI) of other household members is a proxy that takes into account both months worked as well as current working hours. It is calculated as the number of months worked/12 multiplied with current working hours expressed as a percentage of a full-time job ( $\geq 35 \mathrm{~h}$ seen as $100 \%$ ). Hence, if someone works full-time full-year, (s)he gets a WI of 1 . 
Appendix: Overview of descriptive statistics for Tables 2 and 4

\begin{tabular}{|c|c|c|c|c|}
\hline & \multicolumn{2}{|l|}{ All workers } & \multicolumn{2}{|c|}{ Part-time workers } \\
\hline & 2008 & 2012 & 2008 & 2012 \\
\hline Part-time & 11.2 & 11.0 & & \\
\hline Involuntary part-time & & & 22.1 & 29.4 \\
\hline Women & 48.4 & 49.8 & 85.3 & 83.1 \\
\hline Low skilled & 17.6 & 14.9 & 24.5 & 21.5 \\
\hline Middle skilled & 52.1 & 50.2 & 50.4 & 51.2 \\
\hline High skilled & 30.3 & 34.9 & 25.1 & 27.3 \\
\hline Age 20_29 & 18.5 & 16.0 & 15.0 & 15.6 \\
\hline Age 30_49 & 55.9 & 54.8 & 56.0 & 53.2 \\
\hline Age 50_64 & 25.6 & 29.2 & 29.0 & 31.2 \\
\hline Not born in country & 8.3 & 9.3 & 10.2 & 13.2 \\
\hline Single & 9.4 & 12.0 & 10.7 & 13.2 \\
\hline Couple & 42.2 & 54.3 & 49.1 & 55.9 \\
\hline Other & 48.4 & 33.7 & 40.2 & 31.0 \\
\hline Average (variance) WI other $\mathrm{HH}$ members & $0.51(0.16)$ & $55.8(0.19)$ & $0.57(0.17)$ & $0.57(0.19)$ \\
\hline 0 children & 59.4 & 47.3 & 52.7 & 43.5 \\
\hline 1 child & 21.0 & 24.6 & 21.1 & 25.0 \\
\hline 2 children & 15.4 & 21.3 & 20.4 & 22.9 \\
\hline$>2$ children & 4.2 & 6.8 & 5.8 & 8.7 \\
\hline $\mathrm{ISCO}=1$ or 2 & 22.8 & 26.9 & 14.7 & 17.1 \\
\hline $\mathrm{ISCO}=3$ & 18.6 & 16.9 & 18.4 & 14.4 \\
\hline $\mathrm{ISCO}=4$ & 11.7 & 10.8 & 16.8 & 15.1 \\
\hline $\mathrm{ISCO}=5$ & 13.5 & 15.2 & 23.2 & 23.8 \\
\hline $\mathrm{ISCO}=6,7$, or 8 & 24.2 & 21.4 & 7.7 & 10.3 \\
\hline $\mathrm{ISCO}=9$ & 9.4 & 8.8 & 19.3 & 19.3 \\
\hline FY working & 90.8 & 90.9 & 81.4 & 81.8 \\
\hline UNEMPL benefit & 5.9 & 6.3 & 10.6 & 11.7 \\
\hline Benefit & 17.0 & 16.9 & 26.6 & 25.5 \\
\hline Total $n$ values & 181,657 & 174,067 & 13,653 & 13,711 \\
\hline
\end{tabular}

Source: EU-SILC 2008 and 2012

Competing interests

The IZA Journal of European Labor Studies is committed to the IZA Guiding Principles of Research Integrity. The authors declare that they have observed these principles.

Authors' information

J. Horemans is PhD candidate at the Herman Deleeck Centre for Social Policy and teaching assistant at the Faculty of Political and Social Sciences at the University of Antwerp.

I. Marx is Associate Professor at the University of Antwerp and Chair of the Department of Sociology there. He directs research on minimum income protection and poverty, especially in relation to labour market change and migration at the Herman Deleeck Centre for Social Policy.

B. Nolan is Director of INET's Employment, Equity and Growth Programme and Professor of Social Policy at the Department of Social Policy and Intervention at the University of Oxford.

\section{Acknowledgements}

The authors would like to thank participants of the FISS 2015 Conference (Hong Kong), Dieter Vandelannoote, Sarah Marchal, and the anonymous referee for useful comments.

Responsible editor: Martin Kahanec 


\section{Author details}

${ }^{1}$ Herman Deleeck Centre for Social Policy, University of Antwerp, SM-184 Sint-Jacobstraat 2, 2000 Antwerp, Belgium.

${ }^{2}$ Herman Deleeck Centre for Social Policy, University of Antwerp, SM-181 Sint-Jacobstraat 2, 2000 Antwerp, Belgium.

${ }^{3}$ Institute for New Economic Thinking, Eagle House-University of Oxford, Walton Well Road, Oxford OX2 6ED, UK.

\section{Received: 29 April 2015 Accepted: 5 January 2016}

Published online: 10 March 2016

\section{References}

Ai C, Norton EC (2003) Interaction terms in logit and probit models. Econ Lett 80(1):123-129

Allègre G, Jaehrling K (2011) Making work pay for whom? Tax and benefits impacts on in-work poverty. In: Fraser N, Gutiérrez R, Peña-Casas R (eds) Working poverty in Europe: a comparative approach. Palgrave Macmillan, Houndmills, Basingstoke

Atkinson T, Cantillon B, Marlier E, Nolan B (2002) Social indicators: the EU and social inclusion. Oxford University Press, Oxford

Bardasi E, Gornick JC (2008) Working for less? Women's part-time wage penalties across countries. Fem Econ 14(1):37-72

Bardonen L, Guio AC (2005) In-work poverty: new commonly agreed indicators at the EU level. Statistics in focus, vol 2005/5

Barrett GF, Doiron DJ (2001) Working part time: by choice or by constraint. Can J Econ 34(4):1042-1065

Bazen S, Salverda W (2015) Household income inequality and part-time employment: the role of dual earners during the financial crisis. Paper presented at the Society for the Advancement of Socio-Economics Conference, London School of Economics, July 2015

Bredtmann J, Otten S, Rulff C (2014) Husband's unemployment and wife's labor supply - the added worker effect across Europe. RUHR Economic Papers No 484

Buddelmeyer H, Mourre G, Ward M (2004) The determinants of part-time work in EU countries: empirical investigations with macro-panel data. IZA DP No 1361

Buschoff KS, Protsch P (2008) (A-)typical and (in-)secure? Social protection and non-standard forms of employment in Europe. Int Soc Secur Rev 61(4):51-73

Cho Y, Newhouse D (2013) How did the Great Recession affect different types of workers? Evidence from 17 middleincome countries. World Dev 41:31-50

Corluy V, Vandenbroucke F (2014) Individual employment, household employment and risk of poverty in the EU. A decomposition analysis. In: Cantillon B, Vandenbroucke F (eds) Reconciling work and poverty reduction: how successful are European welfare states. Oxford University Press, Oxford, pp 94-130

Crettaz E (2011) Fighting working poverty in post-industrial economies: causes, trade-offs and policy solutions. Edward Elgar, Cheltenham

Crettaz E, Bonoli G (2010) Why are some workers poor? The mechanisms that produce working poverty in a comparative perspective. Recwowe: REC-WP 12/2010

de Beer P (2007) Why work is not a panacea: a decomposition analysis of EU-15 countries. J Eur Soc Policy 17(4):375-388

Debels A (2008) Maakt een flexibele job arm? In: Vranken J, Campaert G, De Boyser K, Dewilde C, Dierckx D (eds) Armoede en sociale uitsluiting, vol 2008, Jaarboek. Acco, Leuven, pp 177-198

Dennis I, Guio A-C (2003) Poverty and social exclusion in the EU after Laeken-part 1. Statistics in focus, vol Theme 3-8. Eurostat, Luxembourg

European Commission (2011) European Employment Observatory Review - adapting unemployment benefit systems to the economic cycle, 2011. Publications Office of the European Union, Luxembourg

European Commission (2012) EU-SILC 065: description of target variables: cross-sectional and longitudinal, 2012 operation (Version May 2013)

European Commission (2013a) Employment and social developments in Europe 2013. European Commission, Directorate-General for Employment, Social Affairs and Inclusion

European Commission (2013b) EU Labour Force Survey database user guide: version: November 2013

European Commission (2013c) The impact of the economic crisis on the situation of women and men and on gender equality policies. Publications Office of the European Union, Luxembourg

European Commission (2014) Employment and social developments in Europe 2014. European Commission, Directorate-General for Employment, Social Affairs and Inclusion

Eurostat (2010) EU-SILC: 2008 comparative EU intermediate quality Report version 2 - June 2010, European Commission

Eurostat (2011) EU-SILC: 2008 comparative EU final quality report version 3 - July 2011, European Commission

Eurostat (2015) Main features of the EU-LFS and scope of data. http://ec.europa.eu/eurostat/web/lfs/overview

Fouarge D, Muffels R (2008) Part-time work and childbirth in Europe: scarring the career or meeting working-time preferences. In: Muffels R (ed) Flexibility and employment security in Europe. Edward Elgar, Cheltenham

Gash V (2008) Preference or constraint? Part-time workers' transitions in Denmark, France and the United Kingdom. Work Employ Soc 22(4):20

Ghignoni E, Verashchagina A (2012) Added versus discouraged worker effects during the recent crisis: evidence from Italy. Conference paper, 5th ESPAnet Italia conference, September 2012

Goerne A (2011) A comparative analysis of in-work poverty in the European Union. In: Fraser N, Gutiérrez R, Peña-Casas R (eds) Working poverty in Europe: a comparative approach. Palgrave macmillan, Houndmill

Haataja A, Kauhanen M, Nätti J (2011) Underemployment and part-time work in the Nordic countries. Kela/Fpa Online working papers 31/2011

Hakim C (2000) Work-lifestyle choices in the 21st century: preference theory. Oxford University Press, Oxford

Halleröd B, Larsson D (2008) In-work poverty in a transitional labour market: Sweden. In: Andreß H-J, Lohmann H (eds) The working poor in Europe: employment, poverty and globalization. Edward Elgar, Cheltenham

Hijzen A, Venn D (2011) The role of short-time work schemes during the 2008-09 recession. OECD Social, Employment and Migration Working Papers No 115 
Horemans J, Marx I (2013) Should we care about part-time work from a poverty perspective? An analysis of the EU-15 countries. In: Koch M, Fritz M (eds) Non-standard employment in Europe: paradigms. Prevalence and Policy Responses. Palgrave Macmillan, Houndmills, pp 169-189

ILO (1982) Resolution concerning statistics of the economically active population, employment, unemployment and underemployment. The Thirteenth International Conference of Labour Statisticians

Immervoll H, Pearson M (2009) A good time for making work pay? Taking stock of in-work benefits and related measures across the OECD. IZA Policy Paper No 3

Jaumotte F (2003) Female labour force participation: past trends and main determinants in OECD countries. OECD Economics Department Working Papers 376

Kenworthy L (2011) Prospects for the poor. Oxford University Press, Oxford

Khitarsishvili T (2013) The economic crisis of 2008 and the added worker effect in transition countries. Levy Economics Institute of Bard College: Working Paper No 765

Lang C, Schömann I, Clauwaert S (2013) Atypical forms of employment contracts in times of crisis. Etui Working Paper 2013-03

Leschke J (2007) Are unemployment insurance systems in Europe adapting to new risks arising from non-standard employment? DULBEA Working Paper No 07-05RS

Leschke J (2012) Has the economic crisis contributed to more segmentation in the labour market and welfare outcomes? etui working paper 201202

Lohmann H (2009) Welfare states, labour market institutions and the working poor: a comparative analysis of 20 European countries. Eur Sociol Rev 25(4):26

Lohmann H (2011) Comparability of EU-SILC survey and register data: the relationship among employment, earnings and poverty. J Eur Soc Policy 21(1):37-54

Marchal S, Marx I (2015) Stemming the tide. What have EU countries done to support low-wage workers in an era of downward wage pressure? ImPRovE Discussion Paper No 15/18 Antwerp: Herman Deleeck Centre for Social Policy-University of Antwerp

Marx I, Nolan B (2014) In-Work Poverty. In: Cantillon B, Vandenbroucke F (eds) Reconciling work and poverty reduction. How successful are European welfare states. Oxford University Press, Oxford, pp 131-156

Marx I, Verbist G (2008) Combating in-work poverty in Continental Europe: the policy options assessed. In: Andreß H-J, Lohmann $\mathrm{H}$ (eds) The working poor in Europe. Edward Elgar, London

Marx I, Vanhille J, Verbist G (2012) Combating in-work poverty in Continental Europe: an investigation using the Belgian case. J Soc Policy 41(1):19-41

Mayard DC, Thorsteinson TJ, Parfyonova NM (2006) Reasons for working part-time: subgroup differences in job attitudes and turnover intentions. Career Dev Int 11(2):145-162

McRae S (1993) Returning to work after childbirth: opportunities and inequalities. Eur Sociol Rev 9(2):15

McRae S (2003) Constraints and choices in mothers' employment careers: a consideration of Hakim's preference theory. Br J Sociol 54(3):317-338

Nolan B, Whelan CT, Maître B (2012) Low pay, in-work poverty and economic vulnerability: a comparative analysis using EU-SILC. Manch Sch 80(1):99-116

Norton EC, Wang H, Ai C (2004) Computing interaction effects and standard errors in logit and probit models. Stata J 4(2):154-167

O'Dorchai S, Plasman R, Rycx F (2007) The part-time wage penalty in European countries: how large is it for men? Int J Manpow 28(7):571-603

OECD (2010) How good is part-time work? (Chapter 4). In: Employment outlook 2010: moving beyond the jobs crisis. OECD Publishing, Paris

Peña-Casas R, Ghailani D (2011) Towards individualizing gender in-work poverty risks. In: Fraser N, Gutiérrez R, Peña-Casas R (eds) Working poverty in Europe: a comparative approach. Palgrave macmillan, Houndmills

Peña-Casas R, Latta M (2004) Working poor in the European Union. Eurofound, Luxembourg

Perrons D, McDowell L, Fagan C, Ray K, Ward K (2007) Gender, social class and work-life balance in the new economy. In: Crompton R, Lewis S, Lyonette C (eds) Women, men, work and family in Europe. Palgrave macmillan, Houndmills

Ponthieux S (2010) In-work poverty in the EU. Eurostat: methodologies and working papers

Rodgers JR (2003) Are part-time workers poor? Aust J Labour Econ 6(1):177-193

Stier H, Lewin-Epstein N (2003) Time to work: a comparative analysis of preferences for working hours. Work Occup 30(3):25

van Oorschot W (2012) Comparative welfare state analysis with survey-based benefit recipiency data: a theoretical and methodological positioning, with some empirical illustrations. Paper presented at the 2012 Annual ESPAnet Conference, Edinburgh, 6-8 September 2012

Van Rie T, Marx I (2011) Welfare with work? Comparative evidence on benefit and labour income in European countries. Paper presented at the 2011 Annual ESPAnet Conference, Valencia, 8-10 September 2010

Vaughan-Whitehead D (2011) Work inequalities in the crisis: evidence from Europe. Edward Elgar, Cheltenham

Veliziotis M, Matsaganis M, Karakitios A (2015) Involuntary part-time employment: perspectives from two European labour markets. Improve Discussion Paper No 15/02

Wilkins R (2006) Personal and job characteristics associated with underemployment. Aust J Labour Econ 9(4):371-393

Wilkins R (2007) The consequences of underemployment for the underemployed. J Ind Relat 49(2):247-275

Wilkins R, Wooden M (2011) Economic approaches to studying underemployment. In: Mayard DC, Feldman DC (eds) Underemployment: psychological, economic, and social challenges. Springer, New York, pp 13-34 